\title{
Flags and Landscapes: \\ Border Art from the Australian Goldfields
}

In 1993, eighty-five paintings from the Australian town of Kalgoorlie, executed with cheap paints on cardboard and canvas board, were exhibited in San Diego by the Border Art Workshop/Taller de Arte Fronterizo (BAW/TAF). The BAW/TAF was by then well known for conceptual, political, and performative works that addressed the problem of living beside and between the border between Mexico and the United States. By contrast, the Kalgoorlie artists were unknown and their work was exhibited unnamed. Their rough, naive paintings of Aboriginal Australian flags and landscapes were made on the streets of a mining city hostile to its Aboriginal population (see for example Figures 1 and 2). The San Diego exhibition enables us to think about this Australian collection as border art, a term that was conceived to describe art from the borderlands of Mexico and the United States (Sheren 2016). The nature of border art, who it belongs to and what it means, has been contested by the artists and institutions of this region as it represents the politics of border crossing, identity and labour (see Berelowitz 1997). Borders are after all not only geopolitical, but are cultural, economic and racial as well. To cross into the United States, for example, is to be harassed by the border patrol, the police and more established migrants for being poor and Mexican (Vila 2003a). So it is that borders are reproduced within nation-states as much as outside them. They are infra-national as well as territorial. This has long been recognised by border theory, that takes borderlands across the world as a field of study (Wilson and Donnan 2012, 7-9).

\section{The One Tree Project}

Kalgoorlie in Western Australia is the site of an infra-national border between Aboriginal people and settlers, dating back to their arrival in the region to establish gold mines in the 1890s. While Australia has been famously defined by Patrick Wolfe as a settler-colonial country because of the attempted genocide of its Indigenous population (Wolfe 2006), here the local Wongathi population survived in missions, on government settlements, as labourers on pastoral operations and as so-called fringe dwellers living in camps on the outskirts of Kalgoorlie (Muller 2014). In the 1990s, and despite decades of government reform, this exclusion was still embedded in the culture of Kalgoorlie, in a geography of poverty and race. The term fringe dwellers is a double edged term, as it is used both disparagingly and to focus upon the plight of those marginalised by discrimination (see Bropho 1980; Reynolds 1990, 129-163). In the 1990s it was adopted by The Kalgoorlie Miner newspaper to criminalise and further marginalise the town's Aboriginal population. The duplicitous ideology of fringe dwelling is best represented by Nene Gare's 1961 novel of the same name. It tells the story of an Aboriginal family attempting to move from a fringe camp into housing in the settler suburbs. The family try to cross the border between one socioeconomic situation and another, but as the novel makes clear, the pressures on Aboriginal families to effect such a transition are too great. The expectations of settler society clash with responsibilities to the Aboriginal community, and the family does 
not succeed in moving into a suburban home. By the end of the story they have returned to a humpy, a makeshift shelter, among others in the bush on the edge of the town.

In Kalgoorlie in the 1990s the homeless people being described as fringe dwellers barely numbered in the hundreds, next to a population of tens of thousands of settlers. Even though they were so few, they presented a problem in being all too visible on the town's streets (Kalgoorlie Miner, March 28, 1992). At night many camped in poverty without blankets, wood for fires, and proper sanitation (Kalgoorlie Miner, March 19, 1992). The situation had reached a crisis in 1991 and 1992 as wet weather meant conditions for the homeless had deteriorated. For this reason the Western Australian government sponsored an art project on Kalgoorlie streets, and around 500 works were made as a part of the Warta Kutju Wama Wanti or One Tree Project between 1991 and 1993. Workshops targeting homeless people were run by artist Nalda Searles, who had grown up in the region and had been weaving works from fibres gathered from the natural environment. These workshops would become seminal in Searles's life as an artist, as she became known for working on crosscultural, craft based projects in this region, and especially for her collaborations with Ngaanyatjarra artist Pantjiti Mary McLean (Searles 2009). Searles encouraged participants to make paintings on the back of cardboard packaging scavenged from a local newsagent, supermarket and bottle shop, and sometimes on canvas board and in notebooks. Working out of a vehicle, Searles carried these art materials to locations in and around Kalgoorlie. Initially, she established an outdoor art studio on Brown Avenue, and subsequently in Skinny Park, a cool, grassed nature strip in the central shopping area, and a social hub for Aboriginal people. During 1993, the centenary of Kalgoorlie's founding, police were regularly clearing the park of its Aboriginal users, ostensibly for public drinking. Later, some of Searles's most successful workshops took place out of town, in the surrounding countryside (Figure 3). It was also Searles's foresight that meant these fragile paintings were preserved, as she donated them to the Berndt Museum, one of Australia's most important anthropological collections of Aboriginal art.

The cheap materials from which these One Tree paintings were made betray the way in which these artists were tied to their circumstances. Searles used cardboard so that the artists could not sell their paintings and subsequently spend money on alcohol. Ironically, since the project had been funded as part of an anti-drinking campaign, the strongest cardboard Searles could find was from alcohol packaging, that was manufactured to hold the weight of glass and liquid. She cut and primed the cardboard, preparing it with black or white backings of acrylic house paint. The children who joined the adults to paint many of the One Tree works also lived amidst devastating social problems. During the 1990s petrol sniffing was at its peak across remote Australia. The consequences include damage to the brain, internal organs and nervous system. This is one reason why the One Tree Project has been written about 
as a kind of art therapy, "providing respite from the depression and suffering in these people's lives" (Campanelli 1996, 133).

Initially the paintings were shown on the streets of Kalgoorlie, where Searles carried a mobile exhibition wherever she went. They were also exhibited in the foyer of the Kalgoorlie Commonwealth Employment Service (known as the 'dole office'), before finding their way to the walls of the Perth Institute of Contemporary Art, in Western Australia's capital city. It was here in 1993 that Michael Schnorr (1945-2012), one of the founders of the BAW/TAF saw them, and arranged their exhibition in San Diego. Schnorr's death means that it is no longer possible to ask what motivated him, but we might speculate that he saw something of his own working circumstances within these rough, colourful paintings. As a curator, mural artist and community leader he may have felt that they resonated with the BAW/TAF's dedication to giving a voice to those marginalized by the borders of the nation-state. Schnorr's own murals in San Diego were made in collaboration with the homeless community there, telling subaltern histories of the borderlands region. Schnorr describes "art as a pretext for social and community action," and he may have understood the Kalgoorlie works as an impetus to create change, to reconfigure the border between the Aboriginal and settler populations (quoted in Prieto 1999).

\section{BORDER THEORY}

In some ways, infra-national borders can be more troubling than international ones. Infra-national borders of race and wealth cannot after all, be crossed as easily. The difference between the infra-national and international plays itself out in border theory, where the crossing of borders becomes a metaphor for postmodern subjectivity. Mignolo proposes a border gnosis that articulates the knowing of dialogic identities, to perform one's identity rather than to inhabit it (Mignolo 2000). Ethnographer Pablo Vila is however critical of the way in which the borderlands have been generalised, arguing that for many the border is a more complicated and difficult reality than this version of postmodernism allows (Vila 2003b; Vila 2003c). For Mexicans, crossing the geo-political border does not mean that they can leave their identity behind. Ethnographic scholarship illuminates the discrimination that Mexicans face in Mexico and the United States alike from American employers in both places (Salzinger 2003). As Vila argues, the experience of the border is not necessarily a liberating one (Vila 2003b). Border theory, however, often takes border crossing to be a metaphor for hybridity, migration and transculturation.

The San Diego exhibition enables us to think about these paintings as part of a global condition in which borders are reproduced both on the inside and outside of the nation-state. Such borders were increasingly visible as the twentieth century turned into the twenty-first. So that in 2000, Walter D. Mignolo theorised these infranational, second order borders to be the legacy of colonialism, while in the same year Michael Hardt and Antonio Negri described the way that the regulatory power of states had been eclipsed by supranational structures of capitalism. Structures of 
inequality increasingly played themselves out inside nation-states as much as between them. This aspect of globalisation has been described by Maria Elisa Cevasco as a process of "Brazilianification," in which inequality has become indifferent to geopolitical borders, developing in geographically intensive ways, through gated communities, hijacked high rises and slums in the megacities of Africa, Latin America, and the United States (Cevasco 2004). The proximity of inequality is also visible in less populous towns, theories of globalisation as pertinent to country areas as to cities. In the shadow of the tailings of Kalgoorlie's Super Pit, one of the biggest open-cut mines in the world, lies Ninga Mia, a camp for Aboriginal people, and one that constitutes an invisible border with the settler workers who are housed in Kalgoorlie itself.

\section{Border Art}

The performative strategies of the postmodern were adopted by the artists of the BAW/TAF of the 1990s, who created opportunities around their transnational identities. So that, as the One Tree works were being made on the streets of Kalgoorlie, one of the founders of the BAW/TAF Guillermo Gómez-Peña was performing The Year of the White Bear (1992) in Sydney, on the other side of the continent. In this collaboration with Coco Fusco, he played a caged, tribal Amazonian who had just been discovered by the West. Like BAW/TAF, Gómez-Peña had been invited to Australia for the Sydney Biennale. His performance capitalized on his ability to cross geopolitical borders, from Mexico to the United States, the United States to Australia, and as a Chicano artist who has become Amazonian. Realising the ambitions of border theory to transcend specific cultural and geopolitical boundaries.

Gómez-Peña argues that such performances are a "symbolic gesture," an "allegorical action in a highly charged political territory" (quoted in Sheren 2016, 355). Theirs is a performative identity politics, embodying what Jo-Anne Berelowitz describes as a post-border condition, in which the border is taken as less of a boundary, but one that describes "the experience of living and moving between disjunctive worlds: Indian and European, Mexico and the USA, self and other, home and not home" (Berelowitz 1997, 333). Art is about "the border as a metaphor for the chaos of the border zone," producing a sensibility that transcends the particularity of these identities (Berelowitz 1997, 336).

In the Chicano context, the key text for this cognitive shift is Gómez-Peña's "The New World (B)order: A Work in Progress," a parody of the post-communist, New World Order rhetoric of the US of the early 1990s (Gómez-Peña 1992). Gómez-Peña imagines a borderless United States, or more precisely a United States that is nothing but a border zone. The border is internalized, personal rather than geopolitical. In her art history of this region, Berelowitz describes the art of the early 1990s as border art's second phase, in which the artists stage the interchangeability of borders, the way that 
they play out the similitude of borders and the differences by which they come into being (Berelowitz 1997). In 1991, for example, Carmela Castrejón hung bloodied garments along a newly built border fence, that had just been built out of leftover materials from the Gulf War, to symbolise the bodies that die along both (Figure 4). Such works perform the concept of the geopolitical border, in which various border cultures, riven by conflict, are also tied together by the reproduction of global capital (Berelowitz 1997).

It was at this point in the history of border art that Gómez-Peña and the BAW/TAF were both invited to the 1992 Sydney Biennale. Its theme of the Boundary Rider draws upon an archaic Australian term for workers who maintained the fences of pastoral stations, travelling on horseback for weeks at a time. These workers are romanticized in the literature and history of settler-colonialism in Australia, but were just as commonly of Aboriginal descent (McGrath 1987, 52). For the Sydney Biennale the 'boundary rider' was a metaphor for the place of the artist in society. Talks in Sydney emphasized the way the avant-garde established the border as a trope both in contemporary art and theory (Welchman 1995, 147-168). As Grant Kester argues, since the 1980s it has become increasingly difficult to identify the difference between this "recognized avant garde" of Euro-American artists and the socially engaged practice of groups like BAF/TAW (Kester 2006). By the 1990s the structure of avant-gardism had however given way to debate over transnational social practice, as the end of the cold war gave rise to New Internationalism and postcolonial theories of the cosmopolitan, hybrid and subaltern (Papastergiadis 1994). Borders were being rethought in a postcolonial artworld that had come to embrace concepts that valorised post-national identities. In this spirit, Bond commissioned the BAW/TAF to collaborate with refugee youth from the poor Sydney suburb of Cabramatta, and to exhibit children's work from the North American borderlands. So it is that the BAW/TAF were invited to Sydney not as representatives of their geopolitical specificity, but as artists who were able to generalise the border, to unpack the borders at work wherever they went.

\section{Flags and Landscapes}

In contrast to this transnational era of border art, the flags and landscapes of the One Tree Project insisted upon the sovereignty of place. Flags and landscapes were the two types of images most produced by these artists. The red, black and yellow Aboriginal flag envisages an infra-national border as it symbolises Aboriginal difference and sovereignty within the Australian nation-state, a means by which Aboriginal people can speak back through the identity that has been used to discriminate against them. Although the Australian government adopted the flag as an official one in 1995, enabling it to be flown on government buildings, its designer Harold Thomas was opposed to this incorporation into state symbolism (Gallois 2016a, 24). Like the Kalgoorlie artists, Thomas grew up on the fringes of an Australian town, and the flag expresses an ongoing dissent with government policies 
(Gallois 2016b, 49). Its composition, with a sun sitting in the middle of a horizontal divide, suggests a landscape, and the combination of landscapes and flags suggest that the One Tree paintings testify to the artist's ties to the country that are both political and spiritual.

In this sense, the One Tree exhibition resembles Berelowitz's first phase of border art, when Chicano artists aligned themselves closely with a nostalgic mode of nationalism, wanting to re-establish the Aztec homeland of Aztlán that was once situated across the territories occupied by present day United States and Mexico (Berelowitz 2005, 326-333). Such nostalgia is also evident among One Tree artists, particularly in the subsequent success of Kalgoorlie artist Pantjiti Mary McLean. Through her paintings some of the contradictions of Aboriginal nostalgia can be thought through. During the 1990s McLean was one of Australia's most distinctive artists, having been tutored by Searles to paint in a figurative style that illustrated bush life. McLean and Searles met during the One Tree project, but as if to anticipate her own success McLean painted separately from the painting group on the streets of Kalgoorlie, not wishing to be associated with the drinkers of the town. Making herself distinct from this despairing situation, McLean paints visions of a happy, Arcadian life in the bush, a lost bush life before the European settlement of Australia (Kean 2005). In Camp Dog Chasing Crows (1997, Figure 5), for example, McLean describes:

... a dog who chased kaangka (crows) around the camp. The people here are happy. It has been raining. There is plenty of food and water to drink, and the trees are giving shade for people to rest under during the heat of the day.

(McLean 1997)

With titles such as Happy Camp by the Creek (n.d.) and Healthy Living Before Whitefellas (n.d.), McLean addresses her Aboriginal countrymen as much as the nonAboriginal collectors who would come to buy her work. For McLean's vision presents a possibility of a life in nature that is free of the kind of problems experienced by the border artists of Kalgoorlie. Her paintings are born of a particular Arcadian politics, one that looks beyond the current impasse to a better life (Kean 2005).

The flags exhibited in San Diego also work to create a common sense of Aboriginal experience and community. They allude to an Aboriginal nation born of the community and solidarity that comes out of living on the margins. For more than a hundred years the Kalgoorlie region, and its Aboriginal peoples, have been subject to a rapacious gold mining industry and pastoralism that followed it. In the 1890s, gold brought tens of thousands of settlers, both miners and pastoralists who came to graze sheep to sell to these new markets. Local Aboriginal people were either assigned to work on stations or were moved onto missions in order not to disrupt the development of this internal frontier of Australian capitalism. Aboriginal children were taken to the 
Mount Margaret Mission some 350 kilometres from Kalgoorlie, where they were taught that the traditions of Aboriginal life were "from the devil" (Stanton 1984, 107). Accounts from the 1930s tell of devastating racism in Kalgoorlie itself, where Aboriginal children were threatened with bullets and vicious dogs were set upon Aboriginal people living in the streets (Holmes 1999, 16-18). So it is that the impoverishment and marginalisation of Aboriginal people in Kalgoorlie in the 1990s is intergenerational, the interpersonal politics of economics and race becoming an established culture in the town.

One difference between this Australian borderland and that of North America lies in the duration of their histories. The borderlands of the United States and Mexico are hundreds of years older than the encounter of settlers and Aboriginal people in Australia, that only date back to the late nineteenth century. In North America, the sheer length of relations between peoples has allowed a picture of complexity to emerge, of various peoples encountering one another. As Vila describes it:

What of the Southern Mexican immigrant othered by Northern Mexican natives; the Chicanos othered as pochos by Juarenses' the Mexican immigrant othered by Mexican Americans, Anglos, and African Americans; the people of Mexican heritage--regardless of nationality--othered by Anglos and Blacks; and so on ... (Vila 2003b, 609).

Such cosmopolitanisms also lie behind the history of the Goldfields region and Kalgoorlie, where local Wongathi speakers mix with desert dwelling speakers of Ngaanyatjarra, as well as Noongar and Yamatji people from the east. There is also evidence in the One Tree paintings of an artist from Bidydanga in the north-west and by a Torres Strait Islander. The desert people are a strong presence in the town, as they arrive to go shopping, visit relatives, be hospitalized and go into palliative care. As anthropologist John Stanton writes of the region, "a diversity of experience has served in some respects to minimize regional issues. Traditionally-oriented Desert dwellers live in direct contact with mission-raised (Aboriginal) Christians . . . " (Stanton 1984-5, 321).

Such complex, cross-cultural relations and intra-Aboriginal histories have been documented in elsewhere, but not in Kalgoorlie. In the remote Australian centres of Fitzroy Crossing and Papunya, Aboriginal histories emphasise the way in which people from different desert and freshwater language groups performed ceremonies for each other in order to reconcile life in these larger settlements (Kolig 1995; Scholes 2017). Such a history of Kalgoorlie has not yet been written, and existing histories instead emphasise the settler experience, obfuscating the way in which colonialism brought about a mixing of Aboriginal peoples in a new regime of power (see Goldswain, Sully and Taylor 2014). The Aboriginal cosmopolitanism of Kalgoorlie has also been overwhelmed by the ongoing politics around the status of the so-called fringe dwellers. For Aboriginal people, however, this fringe is more likely to 
be conceptualised in terms of the desert (Stanton 1984-5). At the time of her workshops Searles saw this border as the more significant one. As she told the Kalgoorlie Miner, "Although there is no border in Kalgoorlie, it is the border of city life and bush life" (as quoted in Kalgoorlie Miner, May 19, 1993). Kalgoorlie in this sense lies between a devastated landscape and an archaic one, as it lies on the frontier of capital's expansion between industry and the desert.

Despite the diversity of Aboriginal people in Kalgoorlie, the One Tree works fall into only a few genres, with flags and landscapes dominating their choice of theme. There are also dot paintings, testifying to the influence or presence of Ngaanyatjarra people from the desert to the east. However, the preference for flags and landscapes testify to a shared historical experience in the town, whether the artist is Wongathi, Yamatji, Ngaanyatjarra or Noongar. Many of the landscapes share a vision of settler-colonial incursion, featuring fences and roads that break up their compositions, in antiArcadian visions that speak not so much of placelessness but of the politics of particular places. Other paintings combine the two genres, featuring flags or the colour of flags placed amidst landscapes .

In this, the closest comparisons to the One Tree landscapes are in the Carrolup style, that was first developed by Noongar children at the Carrolup Mission in the 1940s and early 1950s. There are several phases to the history of this Carrolup style, dating from these Mission paintings made to those painted inside prisons and made for sale on the streets of Western Australia's capital city of Perth (Pushman and Smith Walley 2006). Their motifs include grass trees, that are distinct to the south-west of Australia, sunset colours and dead trees. As John Stanton wrote to me in an email dated August 9, 2017, these trees were killed by rising salt levels after extensive land clearing. It is possible to see these motifs in both the Carrolup paintings (Figure 6 is by a youth in the Mission) and in the One Tree works (see Figure 7). The sad truth of this Aboriginal Art movement was that much of its best work was accomplished while its artists were incarcerated, as a part of prison painting and craft programs, or were traded cheaply, as "Hamburgers for Masterpieces" in the words of one scholar of the movement (Eggington 2009, 44). It has been said of the Mission works that they express the sentiments of loss, just as the landscapes made in prison represent a longing for the country from which artists have been confined (Hughes d'Aeth 2002). Here there are very strong borders between those who live on the inside, borders that come to reproduce themselves outside society as these artists made the transition back and forth into and out of the fringes of settler society and back into prison again. There is also a living link between the One Tree artists and those of Carrolup in 
Robert 'Chiko' Dabbs, who was a child at the Carrolup Mission and went on to paint on the streets of Kalgoorlie.

Debates over Aboriginal landscape painting in Australia have largely revolved around Albert Namatjira's (1902-1959) paintings of Central Australia, and there is evidence that both the Carrolup paintings and Namatjira's paintings both derive from the influence of the popular landscape painter Hans Heysen (1877-1968). His reproduced paintings graced the walls of many Australian homes in the early twentieth century, and as curator Chris Malcolm pointed out to me in conversation in November 2017, may have influenced one the best known Carrolup style painters of South-West landscapes, Bella Kelly. The market for Heysen style desert landscapes was also one that Namatjira capitalized on. Yet importantly, the sensibility of Namatjira's paintings and those of the Carrolup style are very different - in Namatjira detail is rendered into the minute distance, while the Carrolup style is characterized by the melancholy of roads and fences disappearing to the horizon. The landscape is not a feast of natural desert colour and detail as it is in Namatjira, but one that has been disrupted by colonisation. So too the One Tree works share with the Carrolup works this tendency to detail the landscape as historical, to depict fallen trees and campfires. So that the landscape painting genre becomes a way of putting the country into relation to its history, of bringing to light not only the place itself, but the relation of this place to itself. These works illuminate the border as frontier, one that makes visible the ecological violence of the settlers.

\section{Conclusion}

Today, race related violence remains a terrible part of life in Kalgoorlie. At the time of researching this essay, conflict between police and protestors erupted in Kalgoorlie over a young Aboriginal boy, Elija Doughty, who was chased and killed by a 4WD driven by a white settler (Perth Now, August 30, 2016; ABC News, 21 July, 2017). The experience of the border in Kalgoorlie is ongoing and intergenerational. In other places in Australia, the rise of a market in Aboriginal art has meant that artists have been able to achieve a degree of visibility, art affording them a degree of recognition for their cultural, linguistic and racial differences. To the east of Kalgoorlie, the Ngaanyatjarra community of Warburton hosts the Warburton Arts Project. To the west, in the state capital of Perth, the Noongar people have had a series of exhibitions of Carrolup style painting (Koolark Koort Koorliny 2003; South-West Central, 2003) and awarded Native Title, the legal recognition of their claims over the country (_). By contrast, the Wongathi people of Kalgoorlie had their claims to Native Title rejected, and remain without an art centre or exhibition history. There are some individual exceptions here. McLean is the most significant, as she made a late life career that began upon meeting Searles on the streets of Kalgoorlie. Her art, however, belongs more to the lineage of the Western Desert and Ngaanyatjarra people than giving a voice to those in the shadows of mining and pastoralism in the Kalgoorlie district. Two other artists from the project, Kresna Cameron and Jason Dimer, have 
kept painting, the first for the Warburton Arts Project and the second dotted works for the commercial tourist market. If there is a national comparison to the flags and landscapes of the One Tree project, they lie instead in art from town camps and missions, spaces neither remote nor completely urban, where Aboriginal people have been left dispossessed and with few resources. There is a marginal art history from these places, that includes artists like Ian Abdulla (1947-2011) and Harry Wedge (1957-2012), and paintings from Tangentyere Artists and Yarrenyty Arltere, art centres based in the town camps of Alice Springs. Such work visualises dispossession by painting the experience of the artists on the fringe of Australian towns.

The exhibition of Kalgoorlie paintings in San Diego allows us to begin to think about the situation of these artists, and more specifically of Kalgoorlie as a border town, where an infra-national border persists between Australian Aboriginal people and settler Australia. They also mobilise the concept of border art, developed to describe an art movement in North America, for use in other situations around the world. This is because borders themselves are a global phenomena, and a way of defining identity both within countries and beyond them. This is why, although its beginnings lie in studies of the North American borderlands, border theory has become a transnational area of study. However, this generalisation has also been one that has led to a schism within border studies, between theories of postmodern subjectivity (Mignolo 2000; Welchman 1995) and scholars of ethnographic specificity (Vila 2003b; Vila 2003c). This schism sounds a note of caution around the conceptualisation of border art, and certainly when it comes to these works from Kalgoorlie. For while North American artists like Gómez-Peña are able to mobilise a multiplicity of identities in their work, the conditions for articulating multiplicity were not available to the Kalgoorlie artists in the early 1990s. Although these people came from different language groups, and their families had experienced different histories of settler-colonialism, they were regarded as fringe dwellers. Their paintings thus expressed an identity of dispossession, flags and landscapes symbolising a border that is specific to shared Aboriginal experience. While the exhibition of the One Tree works in San Diego emphasises the way in which borders are geopolitically interchangeable, this experience is also a regional and national one. These paintings of flags and landscapes insist upon a sovereignty that illuminates the way that borders operate not only internationally but infra-nationally.

\section{Acknowledgements}

Details of the One Tree project that is the subject of this essay are from private conversations with Nalda Searles conducted in 2015 and 2016. My sincere thanks to Nalda, without whom this essay would not have been possible. Thanks also to Natalie Hewlett and Sarah Ridhuan of the Berndt Museum for the time they spent allowing Nalda and myself to look through this collection. This paper was originally presented at the 'Re-imagining Australia' conference in Perth in 2016, and I am grateful to Susan Lowish for the invitation to speak, as well as to my fellow panelists John Dallwitz, 
John Kean, Rene Kulitja and Linda Rive. This paper was greatly improved by comments from its peer reviewers, and from Carmela Castrejón, Chris Malcolm and John Stanton.

\section{References}

Berelowitz, Jo-Anne. 1997. "Conflict over 'Border Art'." Third Text 11 (40): 69-83.

Berelowitz, Jo-Anne. 2005. "The Spaces of Home in Chicano and Latino Representations of the San Diego-Tijuana Borderlands (1968-2002)." Environment and Planning D: Society and Space 23: 326-333.

Bropho, Robert. 1980. Fringedweller. Sydney: Alternative Publishing Co-operative.

Campanelli, Michael. 1996. "Pioneering in Perth: Art therapy in Western Australia." Art Therapy: Journal of the American Art Therapy Association 13 (2): 131-135.

Cevasco, Maria Elisa. 2004. "The Brazilianification of the United States." Paper Presented at the Globalization and Indigenous Cultures Conference, Zhengzou University, China, June 7-15.

Eggington, Robert. 2009. Hamburgers for Masterpieces. Perth: Dumbartung Aboriginal Corporation.

Gallois, Mathieu. 2016a. "The Aboriginal Flag as activist art." Australasian Journal of Popular Culture 5.1 (2016): 19-32.

Gallois, Mathieu. 2016b. "The Aboriginal Flag as art." Australian Aboriginal Studies 2 (2016): 46-60.

Gare, Nene. 1961. The Fringe Dwellers. Melbourne: Sun Books.

Goldswain, Philip, Nicole Sully and William M. Taylor, eds. 2014. Out of Place (Gwalia): Occasional Essays on Australian Regional Communities and Built Environments in Transition. Perth: University of Western Australia Publishing.

Gómez-Peña, Guillermo. 1992. "The New World (B)border: A Work in Progress." Third Text 6 (21): 71-79.

Hardt, Michael and Antonio Negri. 2000. Empire. Cambridge: Harvard University Press. 
Holmes, Sandra Le Brun. 1999. Faces in the Sun: Outback Journeys. Melbourne: Viking.

Hughes-d'Aeth, Tony. 2010. "Rediscovering Carrolup." In Frontier Skirmishes: Literary and Cultural Debates in Australia after 1992, ed. Russell West-Pavlov and Jennifer Wawrzinek, 261-275. Heidelberg: Universitätsverlag Winter, 2010.

Kean, John. 2005. "Remembering Arcadia." In Pantjiti Mary McLean: A Big Story, Paintings and Drawings 1992-2005, edited by Nalda Searles, 12-21. Adelaide: National Tandanya National Aboriginal Cultural Institute.

Kester, Grant. 2006. "Interview with Tim Stott." Circa Art Magazine 117. http://circaartmagazine.website/backissues/c117-article-an-interview-with-grantkester/

Kolig, Erich. 1995. "Darrugu: Secret objects in a changing world." In Politics of the Secret, edited by Christopher Anderson, 27-42. Sydney: Oceania and University of Sydney.

Koolark Koort Koorliny (Heart Coming Home): The Herbert Mayer Collection of Carrolup Artwork. 2013. Exhibition catalogue. Perth: John Curtin Gallery.

McGrath, Ann. 1987. 'Born in the Cattle': Aborigines in Cattle Country. Sydney: Allen and Unwin.

McLean, Pantjiti Mary. 1997. Camp Dog Chasing Crows. Quoted in exhibition didactic, Bush Women, curated by Erin Coates and John Kean. Perth: Fremantle Arts Centre, 2018.

Mignolo, Walter D. 2000. Coloniality, Subaltern Knowledges, and Border Thinking. Princeton: Princeton University Press.

Muller, Craig. 2014. "The 'allurements of the European presence': Examining explanations of Wongatha behaviour in the northern Goldfields of Western Australia." Aboriginal History 38. http://press-

files.anu.edu.au/downloads/press/p308321/html/Text/ch04.xhtml?referer=1268\&page =8\#footnote-13536-29-backlink

Papastergiadis, Nikos. 1994. The Complicities of Culture: Hybridity and 'New Internationalism'. Manchester: Cornerhouse.

Prieto, Antonio. 1999. "Border Art as a Political Strategy.” Information Services Latin America. http://isla.igc.org/Features/Border/mex6.html 
Pushman, Tracie and Robyn Smith Walley. 2006. Koorah Coolingah (Children Long Ago). Perth: Berndt Museum of Anthropology.

Reynolds, Henry. 1990. With the White People. Melbourne: Penguin.

Salzinger, Leslie. 2003. Genders in Production: Making Workers in Mexico's Global Factories Oakland: University of California Press.

Scholes, Luke, ed. 2017. Tjungunutja (from having come together). Darwin: Museum and Art Gallery of the Northern Territory.

Searles, Nalda. 2009. Nalda Searles: Drifting in my own land. Perth: Art on the Move.

Sheren, Ila Nicole. 2016. "The San Diego Chicano Movement and the Origins of Border Art." Journal of Borderlands Studies 17 October 2016.

doi.org/10.1080/08865655.2016.1238314

South-West Central: Indigenous Art from South Western Australia 1833-2002. 2003. Exhibition catalogue. Perth, Art Gallery of Western Australia.

Stanton, John F. 1984-5. "Owners and Occupiers: The Eastern Goldfields Experience." Anthropological Forum V (3): 321-331.

Stanton, John F. 1984. "Conflict, Change and Stability at Mt. Margaret: an Aboriginal Community in Transition." PhD diss., University of Western Australia.

Vila, Pablo. 2003a. "The Polysemy of the Label 'Mexican' on the Border." In Ethnography at the Border, edited by Pablo Vila, 105-140. Minneapolis:

University of Minnesota.

Vila, Pablo. 2003b. "Processes of Identification on the U.S.-Mexico Border." The Social Science Journal 40 (4): 607-625.

Vila, Pablo. 2003c. "The Limits of American Border Theory." In Ethnography at the Border, edited by Pablo Vila, 306-341. Minneapolis: University of Minnesota Press.

Welchman, John C. 1995. Modernism Relocated: Towards a Cultural Studies of Visual Modernity,. Sydney: St Leonards.

Wilson, Thomas M. and Hastings Donnan. 2012. "Borders and Border Studies." In $A$ Companion to Border Studies, edited by Thomas M. Wilson and Hastings Donnan, 125. London: Blackwell. 
Wolfe, Patrick. 2006. "Settler colonialism and the Elimination of the Native." Journal of Genocide Research 8 (4): 387-409. 